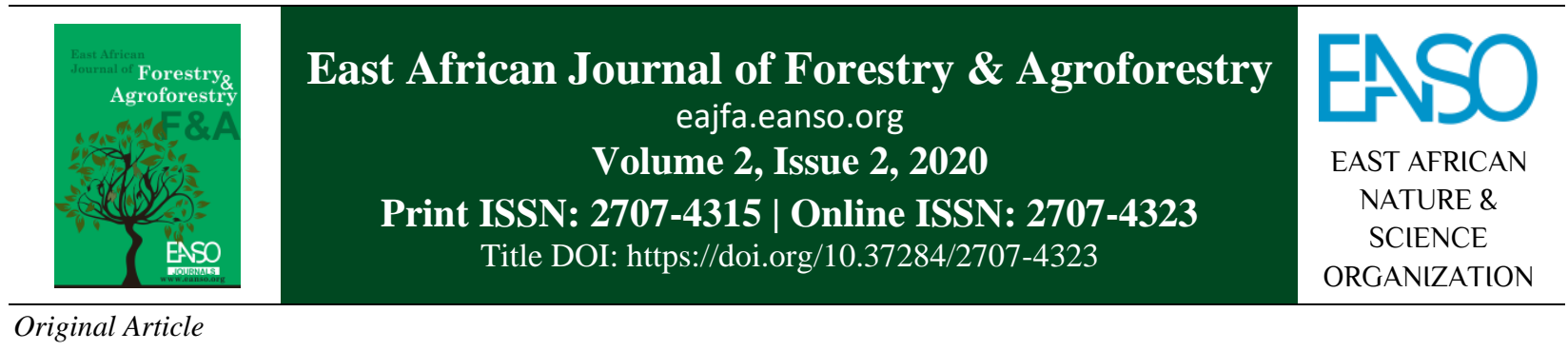

\title{
Comparative Study on Volume Estimation Using a Model with one and Model with two Independent Variables in Meru/USA Forest Plantation, Northern Tanzania
}

\author{
Lucas Kivuyo Likingurainey ${ }^{1}$, Canisius John Kayombo ${ }^{2 *} \&$ Almas Kashindye ${ }^{2}$ \\ ${ }^{1}$ Mbizi Forest Reserve, Tanzania Forest Service Agency, P. O. Box 173, Sumbawanga, Tanzania. \\ ${ }^{2}$ Forestry Training Institute, Olmotonyi. P. O. Box 35091, Dar es Salaam, Tanzania. \\ *Author for Correspondence email: kayombo33@yahoo.co.uk or kayombocanisius@ gmail.com
}

Article DOI: https://doi.org/10.37284/eajfa.2.2.236

\section{Article history: ABSTRACT}

10 November 2020 Worldwide, the management of forests has been known to rely on the determination of the size of tree stands. The size of tree stands is determined

Keywords: based on dimensions that include the diameter and the marketable height

Comparative Study,

Tree Species Volume,

Independent Variables,

Meru/USA Forest,

Northern Tanzania. through the volume equation. The volume is often evaluated from the diameter. It can however also be measured directly on felled trees or logs. It is difficult to obtain the volume for the stand trees directly, so, models were developed to tackle the situation based on standing trees' variables like diameter and height in order to simplify volume estimation because it is more closetful and difficult to measure direct volumes for standing trees. The general objective of this study was to estimate trees' volume using one and two independent variables. Systematic sampling was used to allocate the plots on which the diameters of the trees were measured, and counted for the number of individuals (trees stems). The Relascope was used to assign the trees to be considered in the set plot while a diameter tape measure was used for diameter (DBH) measurements and the already measured trees were marked (using marker pens, paints and chalk). Data recording sheets and a handheld GPS were used for recording coordinates. The study findings revealed that having a model with two independent variables; $D B H$ and $h e i g h t(H)$ is more accurate compared to the model with one independent variable.

\section{APA CITATION}

Likingurainey, L., Kayombo, C., \& Kashindye, A. (2020). Comparative Study on Volume Estimation Using a Model with one and Model with two Independent Variables in Meru/USA Forest Plantation, Northern Tanzania. East African Journal of Forestry and Agroforestry, 2(2), 54-63. https://doi.org/10.37284/eajfa.2.2.236 


\section{CHICAGO CITATION}

Likingurainey, Lucas, Canisius Kayombo, and Almas Kashindye. 2020. "Comparative Study on Volume Estimation Using a Model with one and Model with two Independent Variables in Meru/USA Forest Plantation, Northern Tanzania". East African Journal of Forestry and Agroforestry 2 (2), 54-63. https://doi.org/10.37284/eajfa.2.2.236.

\section{HARVARD CITATION}

Likingurainey, L., Kayombo, C., and Kashindye, A. (2020) "Comparative Study on Volume Estimation Using a Model with one and Model with two Independent Variables in Meru/USA Forest Plantation, Northern Tanzania”, East African Journal of Forestry and Agroforestry, 2(2), pp. 54-63. doi: 10.37284/eajfa.2.2.236.

\section{IEEE CITATION}

L. Likingurainey, C. Kayombo, and A. Kashindye, "Comparative Study on Volume Estimation Using a Model with one and Model with two Independent Variables in Meru/USA Forest Plantation, Northern Tanzania”, EAJFA, vol. 2, no. 2, pp. 54-63, Nov. 2020.

\section{MLA CITATION}

Likingurainey, Lucas, Canisius Kayombo, and Almas Kashindye. "Comparative Study on Volume Estimation Using a Model with one and Model with two Independent Variables in Meru/USA Forest Plantation, Northern Tanzania". East African Journal of Forestry and Agroforestry, Vol. 2, no. 1, Nov. 2020, pp. 54-63, doi:10.37284/eajfa.2.2.236.

\section{INTRODUCTION}

It has been known that volume is widely used to measure the amount of wood in the processes of estimating the economic value or commercial utilization (Ferguson, 2013). It has been reported that the tree volume, which is estimated from the measured $\mathrm{DBH}$ is used to determine the forest structure (Picard et al. 2012).

\section{Volume Estimation}

The sustainability of forest stands is grounded on the management efforts as a result of decisions made after having determined the amount and quality of forest resources (Dau et al. 2015). The estimation of the managed forest stand is obtained through tree volume of the marketable size of timber and non-timber forest products and is done using the recommended forest mensuration techniques, and the use of tools and equations (Malata et al. 2017). The volume approximations using mathematical equations are useful for forest management planning (Masiero et al. 2019). It has been highlighted that models are essential for forest planning, produce estimation, prediction, and regulation of harvests (Hlaing et al., 2017). The generalized allometric models are usually employed to evaluate timber the volume in various countries (Kebede \& Saramosse, 2018). These models are purposed to conceal an extensive spatial size that sometimes varies from their origin's localities (Mugasha et al., 2013). Nevertheless, it is great to note that different timber species demonstrate different growth feedback to different site conditions and associated management prescriptions (Malimbwi et al., 2016). Other scholars such as Nordstrom et al. (2019). noted that the usefulness of generalized models is not without some limitations for effective decision support in forest management. It has been stated that even though these models give out useful volume estimation insights into most or wider forest management applications, site- and species-specific volume modelling would precisely guide operational decisions affecting commercial timber plantation management (Malimbwi et al., 2016).

The development of localized models supports in both identifying the basic variables constructs of the model and in maximizing the timber value (Malimbwi et al., 2016). Quantifying ecosystem services such as carbon sequestration, biodiversity conservation, and water uses is done by the measurement of forest resources. There is a requisition for carbon and bio-mass consideration for the global warming initiatives and the REDD program (Henry et al., 2013). It has been stated further that estimates of volume are useful for evaluation and monitoring of the commercial potential of the forest for fuelwood and timber production and for yield potentials (Tavani et al 2009). Knowledge on the developing stock is also necessary for understanding the biological dynamic and the capacity of productivity of the forest stands and grants managers the capability to govern stands 
within the limits of enduring, as defined by their dynamics of augmentation (Garcia, 2003).

Decision-making in forest management, estimation of growing stock, timber valuation, and allocation of harvest areas is ensured using the established equations in forestry. Avery and Burkhart (2002) mentioned that the volume equation could be utilized to estimate the standard content of various species and sizes of standing trees. Any natural forest stand is expressed for its growth in terms of height and diameter (DBH) (Akindele and Lemay, 2006)

There are few models that have been established for natural forests, although it has been indicated that the volume models have been developed for many plantation species (Moser and Hall, 1969). The previous volume estimates were based on the approximation of DBH and basal area because of the difficulties in measuring the heights and diameters of all trees of a specified stand (Mathew et al., 2016). These variables are required to calculate the quantity using formulas especially when the form factor is not available (Shrestha et al., 2003). Based on the DBH (cm), the volume estimates and height are subjected to deceptions emanating from the stem form variation of a tree (National Research Council of Canada, 2008).

\section{Variability in Volume Estimation}

The stem volume has been stated as a function of a tree's height, basal area, shape, and depending on definition, bark thickness (Dau et al. 2015). One of the most difficult parameters to measure has been reported to be stem volume because an error in the measurement or assumptions for any one of the above factors will propagate to the volume estimate (Mohammadia et al. 2019). The measurement and interpretation of the volume estimate depend on the units of measurement, standards of use, and other specifications, then volume is frequently measured for specific reasons (Gregoire et al., 1986; Kershaw et al., 1986; Schreuder et al., 1993). There is the availability of direct and indirect methods for estimating volume Kershaw et al., 1986). The volume measure of these sections' stem, the theoretical or actual sections tends to be divided by the direct, while volume tables, volume equations, integrating taper equations, variance reduction methods are included in the indirect methods (Alder, 1980). Volume tables were compiled by summarizing the volume of trees in DBH $(\mathrm{cm})$ and height classes before the general availability of computers (Gregoire et al., 1986). Volume equations are developed now.

\section{Models Uncertainty}

\section{Volume Equations Based on One Variable}

Initially, one element equation was contrived appertaining to the volume diameter, after $\mathrm{R}^{2}$ for each model was examined, the RMSE for the data collected from the field was then computed was computed (Koirala et al, 2017). The quantity of $\mathrm{R}^{2}$ in two-variable volume models was higher as compared to that in one-variable volume models (Moosavi \& Ghassabin, 2018). Generally, the volume equations as regards to one variable equation have got lower $\mathrm{R}^{2}$ in association to the volume equation based on two variables, $v=v(d$, h). Even though in certain cases, the number of $\mathrm{R}^{2}$ in volume equations, according to one variable was more than that in Volume equations in reference to two variables (West, 2009).

\section{Variation}

The precision and cost of estimating sample tree volume is improved by variance reduction using the knowledge contained in taper functions ( $\mathrm{Li}$ and Weisktteli, 2010). Basically, there is always a sectional area and cumulative volume at any height up the tree since the taper model predicts the tree's shape (Mohammadia et al. 2011; Weiskittel, 2010). A sample height on the tree is selected and the bole measured. The difference between the measured and predicted size at that height is used to correct the volume estimated from the original taper equation Gregoire et al., 1986). Numerous methods differ in the way the sample height is selected and the way the original estimate is corrected (Dixon and Comp, 2002; West, 2009). According to the aim of the measurement and local traditions, measurement and projection of wood cubic volume may refer to total stem volume, total tree volume (Kohl \& Marchetti, 2016). For aboveground, estimates may include or exclude the stamp, and the volume estimates may include or exclude bark and, for aboveground estimates, include or exclude the 
stump (Manyanda et al., 2019). The volume is always being expressed in cubic metres and usually expressed in cubic meters (Masiero et al. 2019); however, sometimes is being articulated in other units of the standing trees from such measurements as diameter, or diameter plus merchantable height, using a volume equation a log rule (Arney, 1972). Volume is often estimated from reduction such as minimum diameter or piece length, but it can also be measured directly on felled trees or $\operatorname{logs}$ (Oderwald et al., 2009). Sectioning of the tree into smaller pieces assumed to be cylinders is done by direct volume measurement (Pitkanen et al. 2019). When the tree volume is assumed for processed products or stacks of logs by measuring dimensions (Gregoire et al., 1986), the common idea is always required for better estimation of volume. Omission of a local equation, it is likely to employ geometric relationships for volume approximation (Koirala et al., 2017).

A separate stemmed tree is between that of a cone or cylinder, with the volume frequently lying between 0.40 and 0.45 times that of an equivalent cylinder (Hasennauer, 2006; According to Masiero et al (2019) utilizing a value of 0.42 , in the absence of a local equation, an equation can be derived to estimate the cubic volume of wood as given below, and this equation will always give an overestimate of the volume of open-grown trees with more conic form, underestimate the volume of trees with more cylindrical form, and for species with complex forms may need to be modified (Gregoire et al., 1995). This does not give out a first estimation that can afterwards be modified following local experience (Özçelik, 2008). In the absence of local equations, the cubic volume of wood for standing trees may be approximated by the following equation $V=0.42 * B * H$; where $\mathrm{B}$ is the basal area at breast height (1.3 $\mathrm{m}$ from the ground) and $\mathrm{H}$ is a merchantable height.

The accuracy in tree stand parameters has been an interfering factor in forest resource assessment activities because of tediousness (time-consuming), partial reading, taking representative sample as assumption and boastfulness (Mastero et al., 2019). The resource assessment involves the systematic sampling of the existing property or assets focusing on a reliable number of sample plots reflected from the sampling intensity to capture the best representative data (Gregoire et al., 1995). Parameters including the number of trees, diameter, and height by using sample plots have to be considered thoroughly (Cailliez, 1980; Gregoire et al., 1995). The accuracy of tree stands parameters are grounded on the number of sample plots to ensure smooth plots and the number of variables that help to capture the accuracy volume when the model is used for volume estimation (URT, 1992).

URT (1992), reported that well-collected data are meant to solve the problems faced during forest resource inventory. Apart from the existing vivid challenge, there remains very little knowledge on how the accuracy of stand parameters can be obtained based on a number of standing variables. This study focused on the comparative study of the volume estimation using one and two independent variables. It was assumed that there was a difference in the level of accuracy between the volume estimated by using a model with one independent variable and that estimated by the model with two independent variables.

\section{MATERIAL AND METHODS}

\section{Description of Study Area}

The research was carried out at the Narok compartment in Meru/USA forest plantation with an area of 4.8 ha. The site comprised of Pinus patula species aged 20 years. The Meru/USA Narok range forest plantation is located $20 \mathrm{~km}$ northeast side of the city of Arusha; the forest is accessed from all-weather road branching at 3.4-10 $\mathrm{km}$ from the Moshi-Arusha-Nairobi highway. It lies between latitude $3^{0} 15^{\prime}-3^{0} 18^{\prime}$ south and longitudes $36^{0} 4^{\prime}-36^{0} 42^{\prime}$ east (Garmin GPS). Also, the study area is located at the calculated coordinate of latitude $03^{0} 17^{\prime}$ '09.7' ' and longitude $036^{\circ} 38^{\prime} 49$ (URT, 1998).

The Meru/USA Forest plantation is located situated on the lower slopes of Mount Meru. The slopes are moderate with a gentle slope in the Lakinoi, Olmotonyi, Narok, and Oldonyosambu, while in Nading'oro and Kilinga the slopes are steep (URT, 1998). In some compartments, the slopes are very steep, with gradients as high as $60 \%$. The slopes are often intersected by numerous perennial and periodical streams such as Engareolmotonyi, 
Selian, Narok, and Themi rivers which flow down the Mountain. Generally, the altitude ranges from $1500 \mathrm{~m}$ to $2500 \mathrm{~m}$ above sea level (URT, 1998).

\section{Figure 1: Map showing Narok \& Themi compartments in Meru Forest Project}

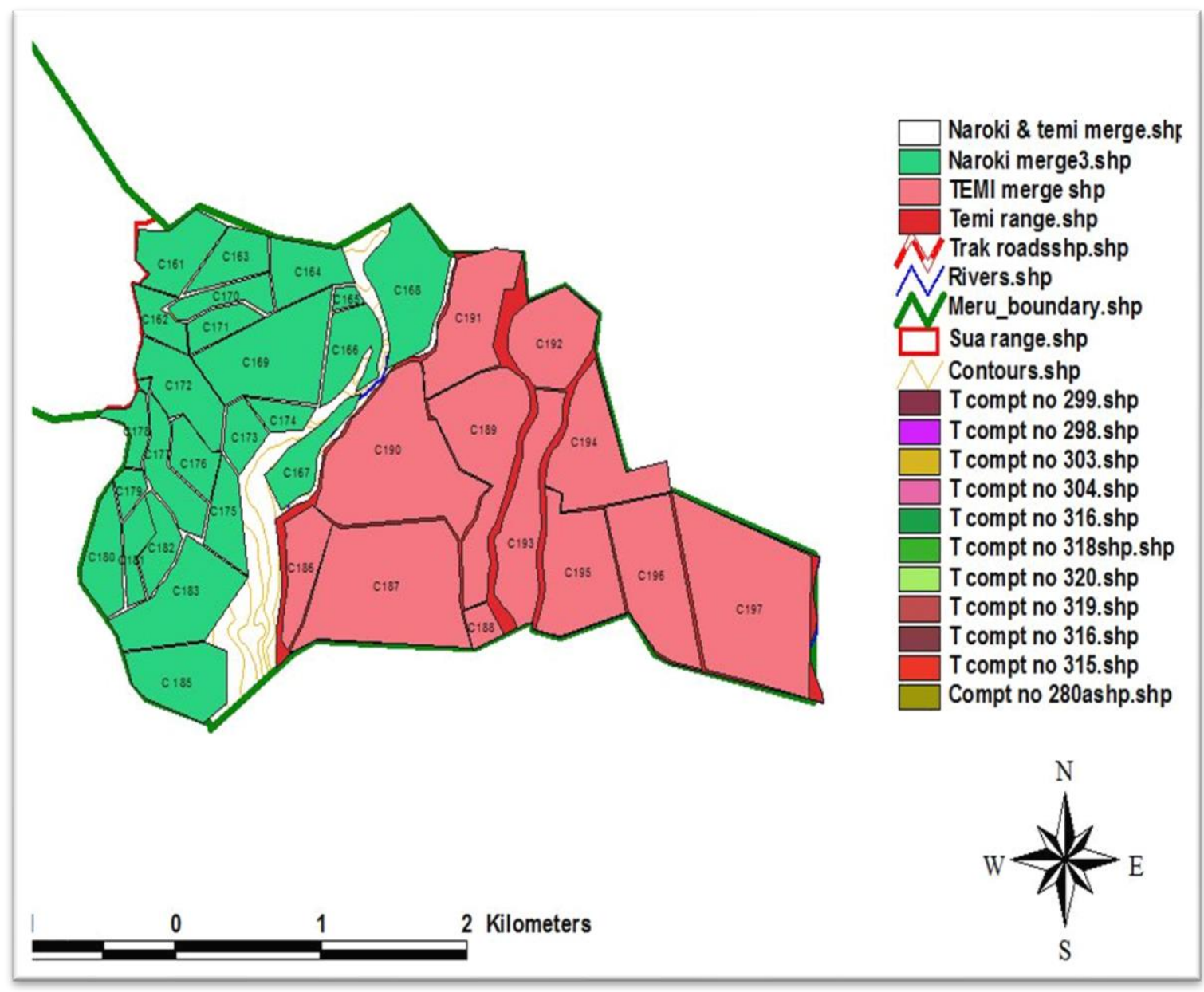

The study area has a variety of vegetation, but this study focused on the compartment with Pinus patula (pines) only. The climate of the area is of oceanic rainfall with continental temperatures. Nearest rainfall stations are Arusha and Olmotonyi; for five years, the average rainfall is $853.74 \mathrm{~mm}$ (URT, 1998). There are two rainy seasons from November to December for short rains and January to May for long rains. Rainfall is highest in Narok, Themi, and Kilinga and becomes less towards Oldonyosambu (URT, 1998). The soil type of Meru/USA is andosols on a volcanic stone which is young (basalt lava), rich in nutrients and alkaline (soda). The soil forms acidic lithosols since its leached at higher altitudes (URT, 1998).

\section{Sampling Techniques}

Systematic sampling (Schreuder et al. 2004), was used to allocate the plots on which the measurement of diameters and counted number of trees were taken simply because the area to be measured was of homogeneous vegetation. The sampling intensity was obtained by taking the ratio of an area to be sampled to the total area of the compartment being expressed in percentage (\%), for this research, an 
intensity of $6 \%$ of the whole population was desired as a representative to drawn the conclusion.

The sample size was 0.288 ha $\left(2,880 \mathrm{~m}^{2}\right)$ calculated from a total area of $4.8 \mathrm{ha}\left(48,000 \mathrm{~m}^{2}\right)$;

$\mathrm{n}=\frac{6 \%}{100 \%} \times 4.8 \mathrm{ha}=0.288$ ha.

Plot size (PS)

PS $=\frac{0.288}{5}=0.0576$ ha $\left(576 \mathrm{~m}^{2}\right)=24 \mathrm{~m} \mathrm{x} 24 \mathrm{~m}$

Plot distance

$\mathrm{D}=\sqrt{\frac{\mathrm{TA}}{\mathrm{n}}}=\sqrt{\frac{0.288}{5}}=43.8 \mathrm{~m} \sim 44 \mathrm{~m}$

\section{Data Collection and Data Analysis}

Trees of Pinus patula were measured for the DBH $(\mathrm{cm})$ at $1.3 \mathrm{~m}$ from the ground (Malimbwi et al., 2000), using a diameter tape and recorded (Malimbwi et at., 2000). Heights of trees were measured using Suunto Hypsometer and Blume Leis (Malimbwi et al., 2016). Also, various library materials were consulted during data collection. Bhaska and Ali (2016) stated that the collected data analysed in Ms Excel program with the assistance t-Test through Paired Two Sample for Means and then from those some of it are analysed using models for further interpretation (Table 1). The models were applied to test their plausibility suitability for further use, whereby mean variation and variance were used as statistical criteria (Tong, 2019).

Table 1: Models used

\begin{tabular}{ll}
\hline Type of & Equation \\
\hline A model with one independent variable & $\mathrm{V}=0.0004 * \mathrm{DBH}^{2.2929}$ \\
A model with two independent variables & $\mathrm{V}=\exp \left[-9.6383+0.9991 * \ln \left(\right.\right.$ height $\left.\left.* \mathrm{DBH}^{2}\right)\right]$ \\
\hline
\end{tabular}

Source: (Pastory, 2014)

\section{RESULTS AND DISCUSSION}

\section{Volume Estimation of the Whole Compartment Based on One and Two Independent Variables}

In this study, it was found that the mean volumes estimated through the model with two independent variables differed compared to the mean volume estimated using the model with only one independent variable. The estimated mean volumes by using the model with two independent variables were higher than the mean volume estimated using the model with only one independent variable (model with only one independent variable result to underestimate volume). It has been supported that the function of diameter and height is the volume of a tree (Sumida et al., 2013). Unfortunately, height measurements for standing trees are normally difficult, time-consuming, and costly as compared to $\mathrm{DBH}$. That precision goes with a cost, even though it must be appreciated. For models that only use $\mathrm{DBH}$, there must be well known precise conversion factors that translate the specific relationship between $\mathrm{DBH}$ and height of the particular timber species. There is a significant relationship between variables, which is indicated in the lower values of the coefficient of determination in the models (Malata et al., 2017).

Table 2: Two Paired Sample Means t-test

\begin{tabular}{lll}
\hline & Variable 1 & Variable 2 \\
\hline Mean & 1.088 & 2.012 \\
Variance & 0.293 & 1.737 \\
Observations & 99 & 99 \\
Pearson Correlation & 0.995 & \\
Hypothesized & 0 & \\
Mean Difference & & \\
Df & 98 & \\
t Stat & -11.764 & \\
P(T $<=t)$ one-tail & $9.53059^{-21}$ & \\
t Critical one-tail & 1.660 & \\
P(T $<=t)$ two-tail & $1.9^{-20}$ & \\
t Critical two-tail & 1.984 & \\
\hline
\end{tabular}




\section{Volume Comparison Estimated from the Two Models}

The calculated volume from the model with only one independent variable usually (DBH) is said to come up with varied results when compared with that volume estimated with the model having two independent variables such (DBH \& H) (Chazdon et al. 2016). The findings of this study revealed an underestimation of volume if one variable is used to compare to that estimated using two variables $\left(92.03 \mathrm{~m}^{3}<170.987 \mathrm{~m}^{3}\right)$. This means the results from the study entail a function of including height and DBH in the volume estimation. Caillez (1992) stated that diameter and height are the preferable parameters for accurate calculation of the volume of trees. The study by Mugasha et al. (2019) came up with the findings that SE\% for the base model was found to be relatively higher than that of generalized models and that might have been explained by large variations in $\mathrm{H}$ which could not be explained by DBH alone.

Table 3: Estimated volume using both models

\begin{tabular}{llllll}
\hline Plot no & No of trees & Total Vol. 1 & Mean Vol. 1 & Total Vol. 2 & Mean Vol. 2 \\
\hline 1 & 16 & 23.404 & 1.432 & 46.370 & 2.898 \\
2 & 14 & 15.081 & 1.077 & 27.520 & 1.965 \\
3 & 23 & 22.316 & 0.970 & 39.691 & 1.725 \\
4 & 25 & 28.791 & 1.151 & 53.535 & 2.141 \\
5 & 21 & 18.685 & 0.889 & 32.092 & 1.528 \\
Total & $\mathbf{9 9}$ & $\mathbf{1 0 8 . 2 7}$ & $\mathbf{5 . 5 2 1}$ & $\mathbf{1 9 9 . 2 1 0}$ & $\mathbf{1 0 . 2 5 9}$ \\
\hline
\end{tabular}

Key: Vol. 1: volume using a model with one independent variable; Vol. 2: volume using the model with two independent variables.

\section{Assessment of Model Uncertainty}

\section{Mean}

One way to simplify the volume estimating procedure and at the same time improve the accuracy of tree volume estimates is to make the standard volume equation sensitive to the variation of stem form. The findings from this study revealed a greater mean for the model with two independent variables than the model with one independent variable $(2.012>1.088)$, indicating that height has influence function in volume calculation (the model with high mean will performing well). Lisboa et al. (2018) stated that those biomass results which do not use tree height give less reliability estimates of biomass than an equation that uses height and diameter, even though its reliability is not more than $10 \%$.

\section{Variance $\left(S^{2}\right)$}

The two independent variables were revealed to have higher $S^{2}$ compared to the $S^{2}$ of the volume using one independent variable $(1.737>0.293)$, (refer table 1). Mostly, when the mean and covariance of the input variables vary from those of the data used for model fitting, the variance of prediction errors may be substantially larger than the residual variance obtained during model fitting (Magnussen \& Reed, 2004). The volume estimated using the model with one independent variable has more variation compared to that estimated with one independent variable (DBH only) and the one with DBH $(\mathrm{cm})$ and height $(\mathrm{m})$ (Table 3).

\section{CONCLUSION AND RECOMMENDATIONS}

The findings of the present study showed that the accuracy in tree stand parameters had been a hindering factor in forest resource assessment activities due to tediousness (time-consuming), partial reading, taking representative sample as assumption and boastfulness. Detailed knowledge of forest stands has been reported to have an increasing need, which has been found to be the essential components of forest management. Utilizing the sampling design with transect, random or systematically selected plots so that the final stand parameters can be deduced according to the statistical extrapolation methods, is the traditional method for deriving stand information (Schrender et al., 1993). 


\section{ACKNOWLEDGEMENT}

Many thanks are indebted to the Meru/USA forest plantation staffs, especially Narok Ranger Incharge Mr. Jaffar Hassan Mbongola for his time and cooperation in making the completion of my research possible during data collection.

\section{REFERENCES}

Akindele, S. O., \& LeMay, V. M. (2006). Development of tree volume equations for common timber species in the tropical rain forest area of Nigeria. Forest Ecology and Management, 226(1-3), 41-48.

Arney, J. D. (1968). Calculation of tree volume and surface area by the height-accumulation method. Master's Thesis. Oregon State University

Avery, T. E., \& Burkhart, H. E. (2015). Forest measurements ( $5^{\text {th }}$ Edition). Long Grove, IL: Waveland Press.

Bhaska, S.B. and Ali, Z. (2016). Basic statistical tools in research and data analysis. Indian Journal of Anaesthesia, 60 (9): 662-669. doi: 10.4103/0019-5049.190623

Cailliez, F. (1980). Forest volume estimation and yield prediction: vol. 1 Volume estimation. FAO Forestry Paper 22/1. Rome: Food and Agriculture Organization

Chazdon, R.L., Brancalion, P.H.S., Laestadius, L., Bennett-Curry, A., Buckingham, K., Kumar, C., Moll-Rocek, J. Vieira, I.C.G. and Wilson, S. J. (2016). When is a forest a forest? Forest concepts and definitions in the era of forest and landscape restoration. Ambio, 45: 538-550.

Dau, J.H., Mati, A., and Dawaki, S.A. Sustainable Forest Management: A Review. International Journal of Forestry and Horticulture (IJFH), 1: 33-40.

Dixon, G. and Comp, E. (2002). Essential FVS: A user's guide to the Forest Vegetation Simulator. Internal Rep. Fort Collins, CO: U. S. Department of Agriculture, Forest Service,
Forest Management Service Center. 226p. (Revised: January 7, 2020).

Ferguson, I. (2013) Assessing sustainability in certification schemes. Journal of Australian Forestry, 76:3-4, 183-193, DOI:10.1080/00049158.2013.848509.

García, O. (2003). Dimensionality reduction in growth models: an example. Forest biometry, Modelling and Information Sciences, 1, 1-15.

Gregoire, T. G., Valentine, H. T., \& Furnival, G. M. (1986). Estimation of bole volume by importance sampling. Canadian Journal of Forest Research, 16(3), 554-557.

Gregoire, T. G., Valentine, H. T., \& Furnival, G. M. (1995). Sampling methods to estimate foliage and other characteristics of individual trees. Ecology, 76(4), 1181-1194.

Hasenauer, H. (2006). Sustainable Forest Management. Growth Models for Europe. Springer Berlin Heidelberg, Germany pp 2035.

Henry, M., Picard, N., Trotta, C., Manlay, R., Valentini, R., Bernoux, M., \& Saint-André, L. (2011). Estimating tree biomass of sub-Saharan African forests: a review of available allometric equations. Silva Fennica, 45(3), 477-569.

Hlaing, Z. C., Kamiyama, C., \& Saito, O. (2017). Interaction between rural people's basic needs and forest products: A case study of the Katha District of Myanmar. International Journal of Forestry Research, 2017.

Kebede, B., \& Soromessa, T. (2018). Allometric equations for aboveground biomass estimation of Olea europaea L. subsp. cuspidata in Mana Angetu Forest. Ecosystem Health and Sustainability, 4(1), 1-12.

Kershaw, J. A., Ducey, M. J., Beers, T. W., \& Husch, B. (1986). Forest Mensuration (Fifth Edition). Willey Blackwell

Kohl, M. \& Marchetti, M. (2016). Measurements and Assessments on Field Plots. In Pancel, L. \& Kohl, M. (Eds), Tropical Forest Handbook Second Edition, (pp. 1-51). Springer. 
Koirala, A, Kizha, A, Baral, S. (2017). Modeling Height-Diameter Relationship and Volume of Teak (Tectona grandis L. F.) in Central Lowlands of Nepal. Journal of Tropical Forestry and Environment, 7: 28-42.

Li, R., \& Weiskittel, A. R. (2010). Comparison of model forms for estimating stem taper and volume in the primary conifer species of the North American Acadian Region. Annals of Forest Science, 67(3), 302.

Lisboa, S. N., Guedes, B. S., Ribeiro, N., \& Sitoe, A. (2018). Biomass allometric equation and expansion factor for a mountain moist evergreen forest in Mozambique. Carbon balance and management, 13(1), 23.

Magnussen, S., \& Reed, D. (2004). Modeling for estimation and monitoring. Knowledge reference for national forest assessments, 111 .

Malata, H., Ngulube, E. S., \& Missanjo, E. (2017). Site specific stem volume models for Pinus patula and Pinus oocarpa. International Journal of Forestry Research, 2017.

Malimbwi, R.E., Eid, T. \& Chamshama, S. A. O. (2016). Allometric Tree Biomass Volume Models in Tanzania. Book of Tree Biomass. Department of Forest Mensuration and Management All rights reserved. Printed in Tanzania.

Malimbwi, R.E., Luoga, E.J., Hofstad, O., Mugasha, A.G. and Valen, J.S. (2000). Prevalence and standing volume of Dalbergia melanoxylon in coastal and inland sites of Southern Tanzania. Journal of Tropical Forest Science, 12 (2): 336-347.

Manyanda, B., Mugasha, W.A., Nzunda, E., and Malimbwi, R.E. (2019). Biomass and Volume Models Based on Stump Diameter for Assessing Degradation of Miombo Woodlands in Tanzania. International Journal of Forestry Research, 38: 1-15.

Masiero, M., Pettenella, D., Boscolo, M, Barua, S.K., Animon, I, and Matta, R. (2019). Valuing forest ecosystem services A training manual for planners and project developers. Food and
Agriculture Organization (FAO) of the United Nations Rome. Forest working paper 11, 1-220.

Matthews, R.W., Jenkins, T.A.R., Mackie, E.D. \& Dick, E.C. (2016). Forest Yield: A handbook on forest growth and yield tables for British forestry Commission, Edinburgh. i-iv $+1-$ 92pp. Keywords: forestry, forest management, silviculture, yield tab.

Messager, M. L., Lehner, B., Grill,G., Neveda, I. \& Schmit, O. (2016). Estimating the volume and age of water stored in global lakes using a geostatistical approach. Nature Communication. 7: 7, 13603

Mohammadia, J., Shataee, S., and Babanezhadc, M. (2011). Estimation of forest stand volume, tree density and biodiversity using Landsat ETM+ Data, comparison of linear and regression tree analyses. Procedia Environmental Sciences, 7: 299-304.

Moser, J. W., \& Hall, O. F. (1969). Deriving growth and yield functions for uneven-aged forest stands. Forest Science, 15(2), 183-188.

Mugasha, W. A., Eid, T., Bollandsås, O. M., Malimbwi, R. E., Chamshama, S. A. O., Zahabu, E., \& Katani, J. Z. (2013). Allometric models for prediction of above-and belowground biomass of trees in the miombo woodlands of Tanzania. Forest Ecology and Management, 310, 87-101.

Mugasha, W. A., Mauya, E. W., Njana, A. M., Karlsson, K., Malimbwi, R. E., \& Ernest, S. (2019). Height-diameter allometry for tree species in Tanzania mainland. International Journal of Forestry Research, 2019.

Nordstrom, E., Nieuwenhuis, M., Zoccatelli, D. 2019. Forest decision support systems for the analysis of ecosystem services provisioning at the landscape scale under global climate and market change scenarios. European Journal of Forest Research; 138: 561-581.

NRCC. (2008). Canadian Journal of Forest Research. Journal Canadien de la Recherche Forestière, Vol.38; 6-7. 
Oderwald, R. G., \& Johnson, J. E. (2004). Measuring standing trees and logs. Publication 420-560. Virginia Cooperative Extension, Virginia State University.

Özçelik, R. (2008). Comparison of formulae for estimating tree bole volumes of Pinus sylvestris. Scandinavian Journal of Forest Research, 23(5), 412-418.

Pastory, M. (2014). Estimation of biomass and carbon stock for Pinus patula grown in Meru forest plantations, Tanzania. Remote Sensing of Environment, 80, pp. 88-99.

Picard, N., Saint-Andre, L., and Henry, M. (2012). Manual for building tree volume and biomass allometric equations from field measurement to prediction. Food and Agriculture Organization of the United Nations (FA0) Viale delle Terme di Caracalla 00153 Rome, Italie.

Pitkanen, TP., Raumonnen, P., and Kangas, A. (2019). Measuring stem diameters with TLS in boreal forests by complementary fitting procedure. ISPRS Journal of Photogrammetry and Remote Sensing, 147: 294-306.

Schreuder, H. T., Gregoire, T.G. \& Wood, G. B. (1993). Sampling motherhood for multisource forest inventory. New York, NY: John Wiley and Sons.

Schreuder, H.T., Ernst, R. and RamirezMaldonado, H. (2004). Statistical Techniques for Sampling and Monitoring Natural Resources. General Technical Report RMRSGTR, 126, 1-118.

Shrestha, H. L., Kafle, M. R., Khanal, K., \& Mandal, R. A. (2018). Developing local volume tables for three important tree species in Nawalparasi and Kapilvastu districts. Banko Janakari, 84-91.

Sumida, A., Miyaura, T., \& Torii, H. (2013). Relationships of tree height and diameter at breast height revisited: analyses of stem growth using 20-year data of an even-aged Chamaecyparis obtusa stand. Tree Physiology, 33(1), 106-118.
Tavani, R., Saket, M., Piazza, M., Branthomme, A., \& Altrell, D. (2009). Case studies on measuring and assessing forest degradation: Measuring and monitoring forest degradation through national forest monitoring assessment (NFMA). Forest Resources Assessment Working Paper 172. FAO.

Tong, C. (2019). Statistical Inference Enables Bad Science; Statistical Thinking Enables Good Science. The American Statistician, 73, 246261.

United Republic of Tanzania (URT). (1992). Volume models for single trees in tropical rainforests in Tanzania. United Republic of Tanzania.

United Republic of Tanzania (URT). (1998). Arusha Socio-economic Profile. Arusha: The Planning Commission, Dar es Salaam \& Regional Commissioner's Office.

West, P. W. (2009). Tree and forest measurement. New York, NY: Springer. 